\title{
IMPACT OF TRANSFER PRICING ON FOREIGN DIRECT INVESTMENT IN ROMANIA
}

\author{
I. TACHE ${ }^{1} \quad$ M. P. LUCA ${ }^{2}$
}

\begin{abstract}
The purpose of the study presented in this paper is to analyse the impact of transfer pricing on foreign direct investment (FDI) in Romania. For attaining this goal, we performed a simple linear regression by the least squares method to study the impact of adjustments of tax obligations in the field of transfer pricing on foreign direct investment in the period 2011-2019. We have proved, from a statistical point of view, that there is a relationship between foreign direct investment and adjustments to tax liabilities resulting from transfer pricing.
\end{abstract}

Key words: transfer prices, foreign direct investment, multinational companies, simple linear regression equation

\section{Introduction}

Transfer pricing is interdisciplinary in nature, being under the influence of accounting, taxation, economics and law.

Studies in this field show the economists' constant concern over analysing how multinational companies move their profits, the link between tax rates and reported profits, and the effects of local regulations on decisions to locate multinational companies. We intend to use an econometric model to test the relationship between the level of adjustments to tax liabilities related to transfer prices and foreign direct investment in Romania.

The conclusions reached in this paper are based on the documentation on the existing bibliography in the field, as well as on the use of statistical-mathematical and econometric methods, more exactly a simple linear regression - the least squares method, built on econometric software EViews 7.2. and Excel statistical-mathematical software.

The paper is organized as follows: the following section assesses the link between FDI and multinational companies as main generators of transfer pricing. Section 3 develops our econometric model for testing the relationship between the level of adjustments of

\footnotetext{
${ }^{1}$ Transilvania University of Braşov, ileanatache@unitbv.ro, ORCID ID: 0000-0003-4559-3367

2 Lucian Blaga University of Sibiu, mihaluca2006@yahoo.com.
} 
fiscal obligations related to transfer pricing and FDI in Romania, and the last section offers the conclusions.

\section{Transfer Pricing and Relationship between Foreign Direct Investment and Multinational Companies}

We consider first the links between FDI and multinational companies (MNCs), sometimes called multinational enterprises (MNEs), as the main generators of intragroup transactions and implicitly transfer prices. There are strong links between foreign direct investment and multinational companies, the former being the main financial source for setting up multinational companies.

According to the definition given by the NBR, direct investments represent long-term investment relations between resident and non-resident entities, which involve the exercise by investors of significant managerial influence in the enterprises in which they have invested.

Taking into account the fact that the FDI balance represents the value of all foreign direct investments that have been accumulated until a certain moment (in the analysed case - at the end of the year), the balance of foreign direct investments in Romania (for the period 2011-2019) is as follows:

Table 1

Evolution of FDI balance in GDP for the period 2011-2019 in Romania (mil EUR)

\begin{tabular}{|l|c|c|c|c|c|c|c|c|c|}
\hline Components & $\mathbf{2 0 1 1}$ & $\mathbf{2 0 1 2}$ & $\mathbf{2 0 1 3}$ & $\mathbf{2 0 1 4}$ & $\mathbf{2 0 1 5}$ & $\mathbf{2 0 1 6}$ & $\mathbf{2 0 1 7}$ & $\mathbf{2 0 1 8}$ & $\mathbf{2 0 1 9}$ \\
\hline $\begin{array}{l}\text { FDI Balance } \\
\text { Total * }\end{array}$ & 53.723 & 57.851 & 60.639 & 61.999 & 64.663 & 70.742 & 75.851 & 81.124 & 88.304 \\
\hline Equity & 37.081 & 39.393 & 40.700 & 43.243 & 45.098 & 48.964 & 52.746 & 57.479 & 61.352 \\
\hline $\begin{array}{l}\text { Debt } \\
\text { instruments } \\
* *\end{array}$ & 16.642 & 18.458 & 19.939 & 18.756 & 19.565 & 21.778 & 23.105 & 23.645 & 26.952 \\
\hline GDP* & 131.963 & 133.246 & 143.802 & 150.428 & 160.328 & 170.378 & 187.801 & 204.684 & 223.342 \\
\hline $\begin{array}{l}\text { FDI/GDP (\%) } \\
\text { Balance }\end{array}$ & 40,7 & 43,4 & 42,2 & 41,2 & 40,3 & 41,5 & 40,4 & 39,6 & 39,5 \\
\hline
\end{tabular}

Source: National Bank of Romania, Foreign direct investment in Romania in 2019 (BNR, 2019)

Notes:

* - FDI balances for the period 2011-2012 were recalculated according to the methodology provided by the IMF Manual Balance of Payments and International Investment Position (BPM6)

- FDI balances for the period 2013 - 2016 were revised in December 2019, within the benchmark revision (more information is available at http://www.bnr.ro/Procesul-derevizuire-a-datelor-statistice- 20794.aspx)

** debts minus receivables (claims) in relation to foreign direct investors and companies in their group 
FDI flows, representing new investments that entered the economy in one year, evolved in Romania in the period 2011-2019 as follows:

Table 2

Evolution of FDI flow in GDP for the period 2011-2019 in Romania (million EUR)

\begin{tabular}{|l|r|r|r|r|r|r|r|r|r|}
\hline Components & \multicolumn{1}{c|}{$\mathbf{2 0 1 1}$} & $\mathbf{2 0 1 2}$ & $\mathbf{2 0 1 3}$ & \multicolumn{1}{c|}{$\mathbf{2 0 1 4}$} & $\mathbf{2 0 1 5}$ & $\mathbf{2 0 1 6}$ & $\mathbf{2 0 1 7}$ & $\mathbf{2 0 1 8}$ & $\mathbf{2 0 1 9}$ \\
\hline Total* & 1.700 & 2.489 & 2.712 & 2.421 & 3.461 & 4.517 & 4.797 & 5.266 & 5.173 \\
\hline $\begin{array}{l}\text { Contribution } \\
\text { to equity }\end{array}$ & 4.002 & 2.676 & 2.765 & 4.222 & 3.085 & 3.202 & 2.235 & 2.973 & 2.238 \\
\hline $\begin{array}{l}\text { Reinvested } \\
\text { profit }\end{array}$ & -2.497 & -1.846 & -337 & -1.376 & 510 & 1.138 & 1.733 & 2.573 & 2.783 \\
\hline $\begin{array}{l}\text { Debt } \\
\text { instruments }\end{array}$ & 195 & 1.659 & 285 & -425 & -134 & 176 & 829 & -280 & 152 \\
\hline $\begin{array}{l}\text { GDP* } \\
\text { FDI/GDP (\%) } \\
\text { flow }\end{array}$ & 131.963 & 133.246 & 143.802 & 150.428 & 160.328 & 170.378 & 187.801 & 204.684 & 223.342 \\
\hline
\end{tabular}

Source: National Bank of Romania, Foreign direct investment in Romania in 2019 (BNR, 2019)

Low values of the net flow of FDI can be observed in the analysed period in relation to the gross domestic product (GDP) in 2011. In 2019, it registered the value of 2.3 percent of GDP, decreasing from 2.6 percent in the last two years, mainly due to the sharp increase in 2019 of nominal GDP expressed in euro (+9.1 percent compared to the previous year).

Multinational companies have an important role in the Romanian economy, they carry out international production activities through FDI. Using transfer pricing, they are concerned with tax optimization. In order for the tax result to be lower and, implicitly, for taxation to be lower, these companies can artificially increase their debts within the group.

According to Baniță (2019), approximately $80 \%$ of the companies in the top 100 are multinational companies. Of these, most report low profit compared to turnover, which determines a low profit tax paid by these companies in Romania. Transfer pricing is considered a tool that can help erode the tax base and shift profits.

The evolution of the transfer price adjustments established by ANAF (National Agency for Fiscal Administration) following the fiscal inspections performed for the period 20102019 is presented in the following table:

Evolution of transfer pricing adjustments

Table 3

\begin{tabular}{|c|c|c|}
\hline Year & $\begin{array}{c}\text { Additional tax obligations established } \\
\text { (Income tax and accessories) - million lei }\end{array}$ & Reduction of fiscal losses - million lei \\
\hline 2010 & 13,8 & 5,9 \\
\hline 2011 & 66,6 & 188 \\
\hline 2012 & 11 & 100 \\
\hline 2013 & 4 & 72 \\
\hline 2014 & 28 & 60 \\
\hline
\end{tabular}




\begin{tabular}{|r|c|c|}
\hline Year & $\begin{array}{c}\text { Additional tax obligations established } \\
\text { (Income tax and accessories) - million lei }\end{array}$ & Reduction of fiscal losses - million lei \\
\hline 2015 & 192 & 334 \\
\hline 2016 & 87 & 428,1 \\
\hline 2017 & 60 & 316,4 \\
\hline $2018^{*}$ & 149,3 & 237,7 \\
\hline 2019 & 67,2 & 547,5 \\
\hline
\end{tabular}

Source: ANAF press releases, Annual Performance Reports, www.anaf.ro, (Butnaru and Simionescu, 2018)

*For 2018, we obtained data related to the period January - November 2018 from the "Budget fiscal strategy for the period 2019-2021" developed by the Romanian Government. December 2018 was estimated quantitatively based on information related to January-November 2018 (The Romanian Government - MFP, 2019).

Regarding the way in which the profits are transferred, in the specialized literature we could find two techniques for moving the profits (Ban and Rusu, 2019), respectively:

\section{Incorrect transfer prices set between subsidiaries}

This profit shifting technique involves an underestimation of the prices of goods and services in the event of a transfer from related parties located in high tax jurisdictions to related parties located in low tax jurisdictions, or overvaluation in the opposite situation (Hebous and Johannesen, 2015).

\section{Strategic allocation from the balance sheet}

The strategic allocation technique in the balance sheet involves the transfer of assets that generate profits to related parties located in jurisdictions with low tax rates (Karkinsky and Riedel, 2012), respectively the transfer of liabilities that generate debts to jurisdictions where there are high rates profit taxes (Ruf and Weichenrieder, 2015).

In Romania, we identified studies on direct investments; the relevant ones were those conducted by the Foreign Investors Council (2017 and 2020), such as:

- Foreign direct investments - their evolution and importance in Romania (2017). According to this study, foreign direct investment has fundamentally contributed to building a market economy that operates in Romania;

- Foreign direct investment in Romania (2020), which analysed the evolution of foreign investment in Romania (value, sectors of activity), making also some proposals in this regard.

3. Econometric Model for Testing the Relationship between the Level of Adjustments of Fiscal Obligations related to Transfer Prices and Foreign Direct Investment in Romania

In this section of the paper, we present the econometric study conducted to analyse the impact of adjustments to tax obligations in the field of transfer pricing on foreign direct investment for the period 2011-2019. 
The relationship between investment and GDP has long been studied by economists. We recall the Keynesian theory, according to which investment is the engine of economic growth through the investment multiplier. Considering a closed economy without a government:

$$
\mathrm{Y}=\mathrm{C}+\mathrm{I}
$$

where $C$ is global consumption, $I$ is global investment and $Y$ is GDP or global income.

$$
\Delta \mathrm{Y}=\Delta \mathrm{C}+\Delta \mathrm{I}
$$

In Keynes's view, consumption is a function of income, so the change in consumption is equal to the change in income multiplied by the marginal propensity to consume (MPC).

$$
\begin{aligned}
& \mathrm{MPC}=\Delta \mathrm{C} / \Delta \mathrm{Y} \\
& \Delta \mathrm{Y}=\mathrm{MPC}^{*} \Delta \mathrm{Y}+\Delta \mathrm{l} \\
& \Delta \mathrm{Y} / \Delta \mathrm{I}=1 /(1-\mathrm{MPC}) \\
& \mathrm{k}=1 /(1-\mathrm{MPC})
\end{aligned}
$$

where $\mathrm{k}$ is the investment multiplier.

Thus, investments are considered the engine of economic growth through their multiplier effect. Obviously, both domestic and foreign direct investment create jobs and improve know-how.

The variables included in our study are the established additional tax liabilities (income tax and accessories), taken largely from the ANAF Annual Performance Reports and adjusted with the GDP deflator and foreign direct investment (source: BNR), which were also adjusted with the GDP deflator. The GDP deflator, with the help of which we adjusted the time series, was taken from the Eurostat database, seasonally and calendar adjusted series.

To maintain the variables stationary, we made logarithms of the time series and calculated the first difference. A stationary time series involves constant averaging and variation over time. To test the stationarity of time series, we used the Augmented Dickey-Fuller test. The probability associated with the stationarity tests is below the chosen significance level of $5 \%$ for tax liabilities and below the significance level of $10 \%$ and close to the significance level of $5 \%$ for real FDI (see Figures 1 and 2 below). Thus, the null hypotheses according to which the tested time series are not stationary are rejected. 
Null Hypothesig: DL_FISCAL_OELLGATIONS has a unitroot

Exogenous: Constant

Lag Lenghth. 1 (Automalic- based on SC, maxlago=1)

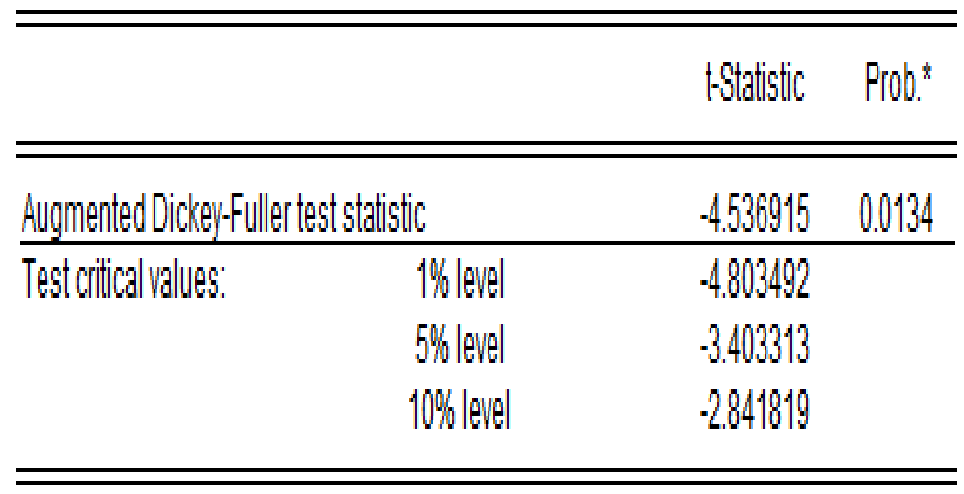

"Wackinnon (1996) one-sided p-values.

Source: Calculations made by the authors

Fig. 1. Testing the stationarity of real tax obligations

Null Hypothesis: DL_REAL_FOREIGN_INVEST has a unitroot

Exogenous: Constant

Lag Length: 1 (Automatic- based on SIC, maxlag=1)

\begin{tabular}{llll}
\hline \hline & & \multicolumn{1}{c}{ t-Statistic } & Prob. ${ }^{*}$ \\
\hline \hline Augmented Dickev-Fuller test statistic & -3.272626 & 0.0533 \\
\hline Test critical values: & 1\% level & -4.582648 & \\
& $5 \%$ level & -3.320969 & \\
& 10\% level & -2.801384 & \\
\hline \hline
\end{tabular}

* Mackinnon (1996) one-sided p-values.

Source: Calculations made by the authors

Fig.2. Testing the real FDI stationarity

We analyse the relationship between real foreign direct investment and fiscal obligations by a simple linear regression. The simple linear regression equation has the following form:

$$
Y=\alpha+\beta^{*} X+u
$$

Null hypothesis:

$$
\beta=0
$$




\begin{tabular}{|c|c|c|c|c|}
\hline \multicolumn{5}{|c|}{$\begin{array}{l}\text { Dependent Variable: DL_REAL_FOREIGN_INVEST } \\
\text { Method: Least Squares } \\
\text { Date: } 05 / 20 / 21 \text { Time: } 20: 00 \\
\text { Sample (adjusted): } 20112019 \\
\text { Included observations: } 9 \text { after adjustments }\end{array}$} \\
\hline Variable & Coefficient & Std. Error & t-Statistic & Prob. \\
\hline$\frac{\text { C }}{\text { DL_FISCAL_OBLIGATIONS }}$ & $\begin{array}{r}0.036151 \\
-0.014586\end{array}$ & $\begin{array}{l}0.007742 \\
0.005732\end{array}$ & $\begin{array}{r}4.669523 \\
-2.544594\end{array}$ & $\begin{array}{l}0.0023 \\
0.0384\end{array}$ \\
\hline $\begin{array}{l}\text { R-squared } \\
\text { Adjusted R-squared } \\
\text { S.E. of regression } \\
\text { Sum squared resid } \\
\text { Log likelihood } \\
\text { F-statistic } \\
\text { Prob(F-statistic) }\end{array}$ & $\begin{array}{l}0.480518 \\
0.406306 \\
0.023105 \\
0.003737 \\
22.26990 \\
6.474957 \\
0.038406\end{array}$ & \multicolumn{2}{|c|}{$\begin{array}{l}\text { Mean dependent var } \\
\text { S.D. dependent var } \\
\text { Akaike info criterion } \\
\text { Schwarz criterion } \\
\text { Hannan-Quinn criter. } \\
\text { Durbin-Watson stat }\end{array}$} & $\begin{array}{r}0.034142 \\
0.029986 \\
-4.504422 \\
-4.460594 \\
-4.599002 \\
2.661914\end{array}$ \\
\hline
\end{tabular}

Source: Calculations made by the authors

Fig. 3. The link between FDI and fiscal obligations

The probability associated with the $\mathrm{F}$ test is $3.84 \%$, so below the chosen significance level of $5 \%$, thus the null hypothesis that $\beta=0$ is rejected.

The coefficient of determination $\mathrm{R}^{2}$ shows that $48 \%$ of the variant of the dependent variable is explained by the independent variable, and the fiscal obligations respectively.

The increase by a percentage in the real fiscal obligations leads to the decrease by 0.0145 percent of the real foreign direct investments.

To confirm that the regression results are valid, we will test the autocorrelation between the normality of the residues and the heteroscedasticity of the errors. Among the consequences of autocorrelation is the oversizing of the coefficient of determination, and the non-normality and heteroscedasticity of the residues imply that the estimators of the parameters in the model do not have the property of maximum likelihood (Jula, 2011).

The Durbin Watson test can take values between 0 and 4 . A value around 2 indicates that the residues do not auto-correlate at the first lag. When the test value is below 2 , it indicates a positive autocorrelation, and when the values are above 2 , the test indicates a negative autocorrelation (Johnston and DiNardo, 1997). In this case, the value is 2.66 . To test whether there is a negative residual autocorrelation, we calculated it.

$$
\mathrm{p}_{\mathrm{k}}=\frac{\sum_{i=k+1}^{n}(x t-x \text { medium }) *(x t-k-x \text { medium }) /(n-k)}{\sum_{i=1}^{n}(x t-x \text { medium }) / n}
$$

pk - the k order of the autocorrelation

$\mathrm{n}$ - number of observations

$\mathrm{x}$ medium - average of residues (Codirlaşu et al., 2010) 
Date: 03/02/21 Time: 18:00

Sample: 20112019

Included observations: 9

\begin{tabular}{cll|llllllll}
\hline \hline Autocorrelation & \multicolumn{2}{c}{ Partial Correlation } & AC & PAC & Q-Stat & Prob \\
\hline \hline & \\
\hline
\end{tabular}

Source: Calculations made by the authors

Fig. 4. Residue autocorrelation testing

Given the probabilities obtained in the figure above, we cannot reject the hypothesis that there is no residual autocorrelation.

To test the normality of the residue, we apply the Jarque-Bera test. The test reveals whether the asymmetry coefficients (Skewness) and Kurtotica (Kurtosis) match the values of a normal distribution, respectively 0 for the asymmetry coefficient and 3 for Kurtotica.

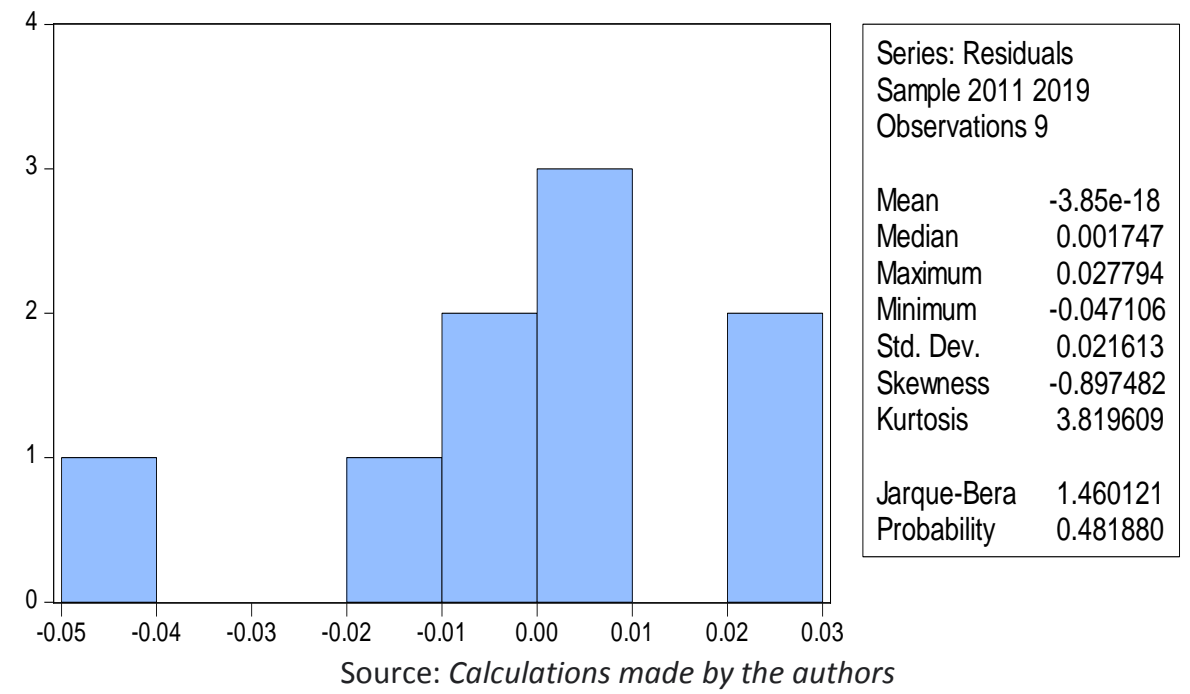

Fig. 5. Residual normality testing

The probability associated with this test is 0.48 , above the chosen level of 0.05 , which indicates that the residues are normally distributed.

Heteroscedasticity indicates that the residues do not have a constant variance (dispersion). The Breusch-Pagan-Godfrey test regresses the quadratic errors according to a constant and the regressors from the initial equation. The null hypothesis is that the 
residues are not heteroscedastic (they are homoscedastic). The probabilities associated with Chi tests are above the chosen significance level of 0.05 , so the null hypothesis is not rejected. The residues are homoscedastic.

\begin{tabular}{|c|c|c|c|c|}
\hline $\begin{array}{l}\text { F-statistic } \\
\text { Obs }{ }^{\star} R \text {-squared } \\
\text { Scaled explained SS }\end{array}$ & $\begin{array}{l}3.192547 \\
2.819013 \\
2.404181\end{array}$ & \multicolumn{2}{|c|}{$\begin{array}{l}\text { Prob. } F(1,7) \\
\text { Prob. Chi-Square(1) } \\
\text { Prob. Chi-Square(1) }\end{array}$} & $\begin{array}{l}0.1171 \\
0.0932 \\
0.1210\end{array}$ \\
\hline \multicolumn{5}{|l|}{$\begin{array}{l}\text { Test Equation: } \\
\text { Dependent Variable: RESID } 2 \\
\text { Method: Least Squares } \\
\text { Date: 05/20/21 Time: } 20: 05 \\
\text { Sample: } 20112019 \\
\text { Included observations: } 9\end{array}$} \\
\hline Variable & Coefficient & Std. Error & t-Statistic & Prob. \\
\hline DL_FISCAL_OBLIGATIONS & $\begin{array}{r}0.000455 \\
-0.000290\end{array}$ & $\begin{array}{l}0.000220 \\
0.000163\end{array}$ & $\begin{array}{r}2.073657 \\
-1.786770\end{array}$ & $\begin{array}{l}0.0768 \\
0.1171\end{array}$ \\
\hline $\begin{array}{l}\text { R-squared } \\
\text { Adjusted R-squared } \\
\text { S.E. of regression } \\
\text { Sum squared resid } \\
\text { Log likelihood } \\
\text { F-statistic } \\
\text { Prob(F-statistic) }\end{array}$ & $\begin{array}{l}0.313224 \\
0.215113 \\
0.000655 \\
3.00 \mathrm{E}-06 \\
54.33641 \\
3.192547 \\
0.117130\end{array}$ & \multicolumn{2}{|c|}{$\begin{array}{l}\text { Mean dependent var } \\
\text { S.D. dependent var } \\
\text { Akaike info criterion } \\
\text { Schwarz criterion } \\
\text { Hannan-Quinn criter. } \\
\text { Durbin-Watson stat }\end{array}$} & $\begin{array}{r}0.000415 \\
0.000739 \\
-11.63031 \\
-11.58649 \\
-11.72489 \\
1.974912\end{array}$ \\
\hline
\end{tabular}

Source: Calculations made by the authors

Fig. 6. Breusch Pagan Godfrey heteroscedasticity test

From a statistical point of view, we proved the existence of a relationship between foreign direct investment and the adjustments of fiscal obligations resulting from the field of transfer pricing.

\section{Conclusions and Personal Contributions}

From a statistical point of view, through the econometric study we proved the existence of a relationship between foreign direct investment and the adjustments of fiscal obligations resulting from the field of transfer pricing.

We came to the conclusion that an increase of one percent in real tax liabilities leads to a decrease of 0.0145 percent in real foreign direct investment.

\section{References}

Ban, C. and Rusu, A. 2019. Pauperitatea fiscală a României. Ce o explică și ce se (mai) poate face. Friedrich Ebert Stiftung.

Banca Națională a României, Investițiile străine directe în România în anul 2019. https://www.bnr.ro/PublicationDocuments.aspx?icid=9403

Baniță, M., 2019. Analiză Top 100 - Profiturile celor mai mari firme din România. https://i0.1616.ro/media/2/2621/33241/19045106/2/top-100-firme-romania-profitsi-cifra-de-afaceri-2018.png 
Butnaru I., Simionescu A., Tax Wise, 2019. Provocări și tendinte în anul 2019 - Prețuri de transfer. In : Conferința -Provocări și tendințe în anul 2019 în materie de fiscalitate, Herlan \& Associates, Sibiu.

Codirlaşu, A., Moinescu, B., and Chidesciuc, A.N., 2010. Econometrie avansată. Bucharest: The Academy of Economic Studies.

Foreign Investors Council (FIC), 2017. Investițiile străine directe - evoluția și importanța lor în România. https://fic.ro/Documents/view/Raport-Investitiile-straine-directeevolutia-si-importanta-lor-in-Romania

Foreign Investors Council (FIC), 2020. Investițiile străine directe în România. https://fic.ro/Documents/view/Investitiile-straine-directe-in-Romania

Guvernul României - Ministerul Finanțelor Publice, 2019. Strategia fiscal bugetară pentru perioada 2019-2021.

Hebous, S. and Johannesen, N. 2015. At Your Service! The Role of Tax Havens in International Trade with Services. CESifo Working Paper Series No. 5414. SSRN: https://ssrn.com/abstract=2627083

Johnston, J. and DiNardo, J. E., 1997. Econometric Methods. 4th Edition. New York: McGraw-Hill.

Jula, D. 2011. Econometrie. http://www.postdoc.acad.ro/data/files/ECONOMETRIE__prof.Jula.pdf

Karkinsky, T. and Riedel, N. 2012. Corporate Taxation and the Choice of Patent Location within Multinational Firms. Journal of International Economics 88(1) DOI: 10.1016/j.jinteco.2012.04.002.

Ruf, M. and Weichenrieder, A.J., 2015. The taxation of passive foreign investment: lessons from German experience. Canadian Journal of Economics, 2012, vol. 45, issue 4, 1504-1528, https://doi.org/10.1111/j.1540-5982.2012.01737.x

\section{Websites:}

https://www.anaf.ro/

https://www.bnr.ro/

http://ec.europa.eu/eurostat 